\title{
Toxocara SPP. EGGS IN PUBLIC SQUARES OF SOROCABA, SÃO PAULO STATE, BRAZIL
}

\author{
Lina Maria De Petrini da Silva COELHO(1), Carlos Yoshizaki DINI(2), Mauro Henrique de Sá Adami MILMAN(2) \& Sônia Maria de OLIVEIRA(3)
}

\begin{abstract}
SUMMARY
The visceral larva migrans (VLM) is a syndrome observed in human infection with helminth larval eggs such as the Toxocara spp. that usually infects dogs and cats. Among the risk factors involved in the occurrence of VLM, particularly important is the size of these animal populations. Sorocaba is a city with a dog population twice as large as that recommended by the World Health Organization. This fact has led to a survey of the presence of Toxocara spp. eggs in public square soils of this city. Thirty squares were selected, fifteen located in the outskirts of the city and fifteen downtown. Soil samples were collected from five distinct sites in the same area. The material was homogenized and drained and $100 \mathrm{~g}$ was mixed with a saturated solution of magnesium sulfate and $5 \%$ potassium iodine. The floating material was analyzed under the light microscope. Toxocara spp. eggs were found in 16 squares, nine of which were located in the outskirts of the city and seven downtown. It was concluded that Sorocaba squares present a high rate of contamination with Toxocara spp. eggs. The squares in the outskirts of the city presented a higher occurrence of these eggs in comparison with those downtown, although the difference was not statistically significant $(\mathrm{p}>0.05)$.
\end{abstract}

KEYWORDS: Toxocara; Public facilities; Larva migrans, Visceral.

\section{INTRODUCTION}

In 1952, visceral larva migrans syndrome (VLM) was described by BEAVER et $a .^{3}$ as the result of prolonged helminth larva migration in unusual organisms, mainly human beings. Human beings contract VLM by ingesting the helminth larval eggs (third phase larvae) mainly Toxocara canis. This infection is known as toxocariasis.

The larva hatches in the intestines and migrates through lymphatic ducts or the portal circulation into several organs, mainly the liver and the lungs and, occasionally, into the heart and the central nervous system, giving origin to the VLM syndrome, or into the ocular globe causing the ocular larva migrans syndrome (OLM) $)^{8,12,18,19}$.

In spite of the differences in the results among studies on the frequency of anti-Toxocara antibodies in human groups of different ages, there is general agreement about a higher prevalence of infection in children $^{2,7,15}$

Although the usual Toxocara hosts are cats and dogs, direct contact with these animals is not considered as a potential risk by some researchers because the helminth eggs eliminated with the host's feces require a minimum period of two weeks to become infective, that is, to reach the $3^{\text {rd }}$ larval phase ${ }^{6,16}$. Nevertheless, it is accepted that dogs kept at home are a risk factor for the occurrence of the VLM syndrome in human beings ${ }^{6}$. Since Toxocara canis is its main agent, the existence of a large dog population in relation to the human population should be considered an important risk factor.

Sorocaba is a city located in the state of São Paulo, Brazil, with about 432,000 inhabitants (IBGE - 1996) ${ }^{11}$ and a dog population of $85,000 \mathrm{dogs}$ that were vaccinated during the rabies campaign of 1999 . Thus the dog population corresponds to approximately $20 \%$ of the human population, whereas $10 \%$ is the maximum percentage recommended by the World Health Organization (WHO ${ }^{22}$. Since only part of the dog population is vaccinated, it may be concluded that this problem is even proportionally more serious.

Reports about contamination of soil samples from public areas have frequently shown the presence of Toxocara eggs, which ranged from $17 \%$ in the city of Rio de Janeiro to $100 \%$ in Londrina, State of Paraná (Brazil) $^{1,4,5,9,10,17,20}$. In Lima (Peru), $80 \%$ of the public squares studied showed Toxocara eggs, but only in $15 \%$ of them were living embryonic eggs found ${ }^{13}$.

These facts, added to the large dog population of this city determined the need to evaluate the contamination of public areas in Sorocaba with Toxocara spp. eggs, which was the objective of the present study.

\section{METHODS}

Thirty public areas in Sorocaba were chosen and analyzed at random.

\footnotetext{
(1) Associate Professor of Parasitology, Centro de Ciências Médicas e Biológicas/PUC-SP, Brazil.

(2) Medical Student (fellowship from PIBIC-CNPq), Centro de Ciências Médicas e Biológicas/PUC-SP, Brazil.

(3) Technician of the Parasitology Discipline, Centro de Ciências Médicas e Biológicas/PUC-SP, Brazil.

Correspondence to: Lina Maria De Petrini da Silva Coelho, R. Maranhão 243, 18035-570 Sorocaba, SP, Brasil. E-mail: lina@ horusnet.com.br
} 
These corresponded to about $50 \%$ of the city squares; fifteen are located downtown and the others in the outskirts of the city.

Material was collected at five equidistant places in each square for better evaluation of the study place. The $5 \mathrm{~cm}$ top layer of the soil samples was taken from an area $10 \mathrm{~cm}$ in diameter, placed in plastic containers and refrigerated for a period of up to 72 hours. Samples from the same area were homogenized and drained. One hundred grams of these soil samples were submitted to a fluctuation process in a saturated solution of magnesium sulfate and 5\% potassium iodine. The fluctuation leftovers were analyzed on six slides stained with lugol and were examined by the same two observers under the light microscope at 100x and 400x magnification.

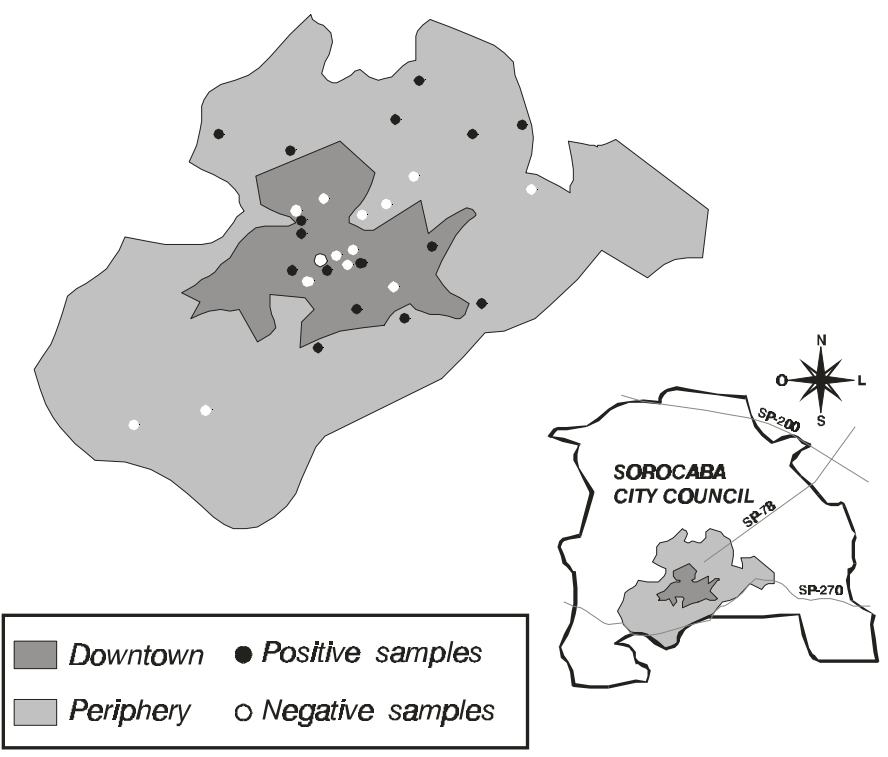

Fig. 1 - Sorocaba map showing the city area and the location of the evaluated squares and respective results.

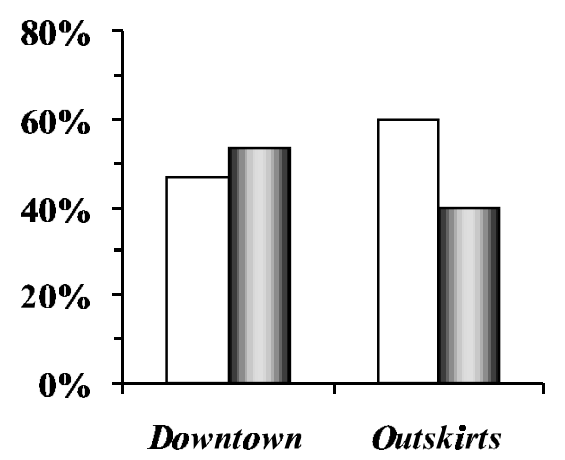

squares

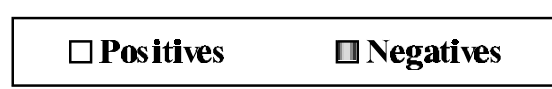

Fig. 2 - Percentage of the Toxocara spp. eggs in downtown and in the outskirts of the city of Sorocaba, São Paulo state, Brazil.
The data obtained were analyzed statistically by the chi-square test ${ }^{21}$.

\section{RESULTS}

Toxocara spp. eggs were found in the soil samples of 16 of the 30 public squares showing a contamination of $53.3 \%$ (Fig. 1). Seven samples $(46.7 \%)$ were positive in the downtown areas and nine $(60.0 \%)$ were contaminated in the outskirts of the city. Figure 2 presents the positive results observed in the squares in the outskirts of the city and in the downtown squares. Statistical analysis did not show any significant difference $(\mathrm{p}>0.05)$.

\section{DISCUSSION}

The contamination of public squares recorded in Sorocaba was important, being higher than the contamination found in Botucatu (17.5\%), in two surveys in Rio de Janeiro (17.0\% and 41.6\%), in Salvador $(24.8 \%)$ and Uberlândia $(23.1 \%)$ and lower than the rates observed in Goiânia $(66.6 \%)$ and Londrina $(100.0 \%)^{1,4,5,9,10,17,20}$. This fact may be the consequence of a large dog population in this region. However, it is important to state that the methodologies employed in this type of survey are extremely variable, preventing a reliable comparison of our results with those obtained in other cities. The only study employing methods similar to those used in the present study was reported by COSTA-CRUZ et $a l .{ }^{9}$ in Uberlândia, state of Minas Gerais.

Analysis of the squares in the outskirts of the city and downtown was done separately. Due to the higher number of cats and dogs loose on the streets it was thought that the squares in the outskirts of the city would present a higher number of places contaminated with Toxocara spp. eggs. As expected, there were more positive areas for these eggs in the squares in the outskirts than downtown, but the difference was not statistically significant.

The present results may indicate a high risk of infection with Toxocara spp., with important recordings of human infection, which should be further analyzed. Meanwhile, the authorities and the population should be alerted to the necessity of controlling the dog population associated with the treatment animals against worms, and about the potential for zoonotic infection in Sorocaba, São Paulo state, Brazil.

\section{RESUMO}

\section{Ovos de Toxocara spp. em praças públicas no município de Sorocaba, São Paulo, Brasil}

A larva migrans visceral - LMV - é uma síndrome causada pela infecção humana por ovos larvados de helmintos como o Toxocara spp., que usualmente compromete o cão e o gato. Dentre os fatores de risco para a ocorrência da LMV, destaca-se o tamanho da população desses animais. Sorocaba é uma cidade com uma população canina duas vezes superior à recomendada pela Organização Mundial de Saúde. Este fato levou à pesquisa da presença de ovos de Toxocara spp. no solo de áreas públicas nessa cidade. Foram escolhidas 30 praças, sendo 15 de regiões periféricas e 15 centrais. Coletaram-se amostras de solo de 5 locais distintos da mesma área. O material foi homogeneizado, tamisado e, em 
seguida, $100 \mathrm{~g}$ foram misturados com uma solução saturada de $\mathrm{MgSO}_{4}$ com KI a 5\%. O material flutuante foi analisado ao microscópio óptico comum. Encontraram-se ovos de Toxocara spp. em 16 praças, sendo 9 periféricas e 7 centrais. Conclui-se que a cidade de Sorocaba apresenta elevado índice de contaminação de suas praças por ovos de Toxocara spp. A periferia apresenta maior ocorrência desses ovos em relação às praças centrais, porém não-significante $(\mathrm{p}>0,05)$.

\section{REFERENCES}

1. ALCANTARA, N.; BAVIA, E.; SILVÃO, R.M. \& CARVALHO, E. - Environmental contamination by Toxocara sp eggs in public areas of Salvador, Bahia state, Brazil. Rev. Soc. bras. Med. trop., 22: 187-190, 1989.

2. ALDERETE, J.M.; YAMASHIRO-KANASHIRO, E.H.; RUBISKY-ELEFANT, G. et al - Aspectos epidemiológicos da toxocaríase em escolares do subdistrito do Butantã, zona oeste de São Paulo. Rev. Soc. bras. Med. trop., 32 (supl. 1): 316, 1999.

3. BEAVER, P.C.; SNYDER, H.; CARRERA, G. et al. - Chronic eosinophilia due to visceral larva migrans. Report of three cases. Pediatrics, 9: 7-19, 1952.

4. CAMPOS, D.M.B.; LEÃO, D.A.; ISAC, E. \& CALIL, F. - Pesquisa de ovos de Toxocara $s p$ em localidades públicas da cidade de Goiania-Goiás. 1. Comparação de métodos e exame. Rev. Pat. trop., 16: 7-11, 1987.

5. CHIEFFI, P.P. \& MULLER, E.E. - Prevalência de parasitismo por Toxocara canis em cães e presença de ovos de Toxocara $s p$ no solo de localidades públicas da zona urbana do município de Londrina, estado do Paraná, Brasil. Rev. Saúde públ. (S. Paulo), 10: 367-372, 1976.

6. CHIEFFI, P.P.; UEDA, M.; CAMARGO, E.D. et al. - Contacto domiciliar e profissional com cães como fator de risco para infecção humana por larvas de Toxocara. Rev. Inst. Med. trop. S. Paulo, 30: 379-382, 1988.

7. CHIEFFI, P.P.; UEDA, M.; CAMARGO, E.D. et al. - Visceral larva migrans: a seroepidemiological survey in five municipalities of São Paulo state, Brazil. Rev. Inst. Med. trop. S. Paulo, 32: 204-210, 1990.

8. CIMERMAN, B. \& CIMERMAN, S. - Parasitologia humana e seus fundamentos. São Paulo, Atheneu, 1999. p. 274.

9. COSTA-CRUZ, J.M.; NUNES, R.S. \& BUSO, A.G. - Presença de ovos de Toxocara spp em praças públicas da cidade de Uberlandia, Minas Gerais, Brasil. Rev. Inst. Med. trop. S. Paulo, 36: 39-42, 1994.

10. FERREIRA, L.F.; OLIVEIRA, E.L. \& CAMILLO-COURA, L. - Sobre a presença de ovos de Toxocara em praças da cidade do Rio de Janeiro. Rev. Soc. bras. Med. trop., 10: 51-54, 1976.
11. INSTITUTO BRASILEIRO DE GEOGRAFIA E ESTATÍSTICA - Contagem da população 1996. http://www.ibge.gov.br/estatistica/populacao/contagem/ spcont97.shtm, 2000.

12. JACOB, C.M.A.; PERES, B.A.; CHIEFFI, P.P. et al. - Síndrome da Larva Migrans Visceral por Toxocara canis. Pediatria (S. Paulo), 9: 9-12, 1987

13. LESCANO, S.A.Z.; CHIEFFI, P.P.; PERES, B.A. et al. - Soil contamination and human infection by Toxocara sp. in the urban area of Lima, Peru. Mem. Inst. Oswaldo Cruz, 93: 733-734, 1998.

14. MELLO, E.O.; YAMASHIRO-KANASHIRO, E.H.; ELEFANT, G.R. et al. - Freqüência de anticorpos antitoxocara em doadores de sangue. Comparação com os níveis de anticorpos encontrados em indivíduos com suspeita clínica de toxocaríase. Rev. Soc. bras. Med. trop., 32 (supl. 1): 58, 1999.

15. MOREIRA-SILVA, S.F.; LEÃO, M.E.; MENDONÇA, H.F. \& PEREIRA, F.E. Prevalence of anti-Toxocara antibodies in a random sample of patients at a children's hospital in Vitória, Espírito Santo, Brazil. Rev. Inst. Med. trop. S. Paulo, 40: 259261, 1998.

16. OVERGAAUW, P.A. - Aspects of Toxocara epidemiology: human toxocarosis. Crit. Rev. Microbiol., 32: 215-231, 1997.

17. PEREIRA DA SILVA, J. - Contaminação de praças do município do Rio de Janeiro por ovos de helmintos. Atas Soc. biol. (Rio de J.), 24: 1-2, 1984.

18. RAYES, A.; TEIXEIRA, D.M.; NOBRE, V. et al. - A síndrome de larva migrans visceral complicada por abscesso hepático e derrame pericárdico: relato de caso. Rev. Soc. bras. Med. trop., 32 (supl. 1): 63, 1999.

19. RAYES, A.; TEIXEIRA, D.M.; NOBRE, V. et al. - Os abscessos piogênicos e a síndrome de larva migrans visceral. Parte 1. O estudo clínico. Rev. Soc. bras. Med. trop., 32 (supl. 1): 64, 1999.

20. SANTAREM, V.A.; SARTOR, I.F. \& BERGAMO, F.M.M. - Contaminação, por ovos de Toxocara spp, de parques e praças públicas de Botucatu, São Paulo, Brasil. Rev. Soc. bras. Med. trop., 31: 529-532, 1998.

21. SIEGEL, S. - Estadistica no parametrica aplicada a las ciencias de la conducta México, Ed. Trillas, 1975.

22. WORLD HEALTH ORGANIZATION/ZOON - Guidelines for dog population management. Geneve, 1990.

Received: 27 July 2000

Accepted: 26 March 2001 